\title{
Ways of doing ethnographic film on British television
}

\section{THE ORIGINS OF ETHNOGRAPHIC FILM SPONSORSHIP BY BRITISH TELEVISION}

Prior to its sponsorship by television, ethnographic film-making in Britain was almost non-existent. Since the pioneering work of Haddon and Spencer at the turn of the twentieth century, the number of British anthropologists who had taken moving image cameras with them to the field had been very few, and even those that had done so, had generally used them not to make documentaries as such, but rather for documentation purposes. Facilities and support for ethnographic film were extremely limited: in contrast to France and the USA, British museums did not support ethnographic filmmaking to any great extent, nor did British research councils or universities. Nor were there any leading individual film-makers, such as Jean Rouch in France, or John Marshall and Robert Gardner in the USA, whose personal example might have served as an inspiration to others. Colin Young, who acted as the initial enabler of Observational Cinema, as described in Chapter Io, was still based in UCLA in the late I96os and it would be some years before he brought his influence to bear on ethnographic film-making back in Britain. ${ }^{1}$

A major reason for the support given to ethnographic films by British television can be traced to the very particular circumstances of British mass media in the post-war period. Since its foundational charter in the I920s, the British national broadcaster, the British Broadcasting Corporation (BBC), had been under a formal obligation to 'educate and inform' as well as 'entertain'. This is generally referred to as the 'Reithian' tradition of public service broadcasting, on account of the role of the first Director General of the BBC, John Reith, in formulating these principles. When it launched a television service in the early I950s, the BBC remained bound by these Reithian principles, as were the 'independent' commercial companies that were awarded television broadcasting franchises later in the same decade. These franchises were assigned on a regional basis and as time went on, 
the various franchise holders operated what was, in effect, an informal division of labour in relation to this obligation to produce educational material: some chose to make films about natural history, others about opera or ballet, others again about the visual arts. The holder of the franchise for the northwest of England, Granada Television, based in Manchester, chose to support the making of ethnographic films. ${ }^{2}$

Why Granada Television should chose ethnographic film-making in fulfilment of its educational remit was due to a set of entirely fortuitous personal circumstances. The chief executive of the company since its formation in I955, Sir Denis Forman, was a man of broad cultural interests, including an interest in anthropology, which stemmed from his reading of The Golden Bough as an adolescent. For the son of a Scottish Presbyterian minister, the encounter with Sir James Frazer's presentation of Christianity as just one more set of religious beliefs, no more securely founded than any other, proved to be a life-changing experience, leading him to reject religion, much to his devout parents' consternation. ${ }^{3}$ Later, as director of the British Film Institute (BFI) in the immediate post-war period, Forman came to admire the works of Flaherty, and the Cooper and Schoedsack classic, Grass, as well as the early works of Jean Rouch.

As he would later confess, he long harboured a personal desire 'to spend time alone in the company of remote tribal people', though he saw no realistic way of doing so, except vicariously, through the works of ethnographic film-makers. Forman also had a keen sense of the major cultural changes taking place as ethnic minorities across the globe came into closer contact with the outside world and he thought it imperative that these ways of life be documented on film before they disappeared for ever. 'I am sure', he wrote in 1985 , 'that one hundred years from now there will be no documentary film material in existence, whether it be of World War Two, or the arrival of the aeroplane, that will surpass in value the record of vanished societies in reaching a better understanding of the human condition as it changes through the centuries.' ${ }^{4}$

It was on account of this idiosyncratic personal interest that Forman's attention was drawn to Piraparaná, a short film about the indigenous peoples living in the Vaupés region of Colombian Amazonia that was submitted to Granada Television sometime in I965. The directors of this film, who had no film-making training whatsoever, were Brian Moser and Donald Tayler. The film had been shot in October-November I96I in the course of an ethnomusicological expedition to Colombia that Moser and Tayler had organised shortly after they graduated from the University of Cambridge. The cameraman, who shot the material on a spring-wound Bolex, was Niels Halbertsma, a Dutch freelancer whom Moser and Tayler had met by chance at a party in Bogotá, while the editor was David Gladwell, who would later go on to have a distinguished career in the feature film 
industry. Since shooting this film, Moser had been working as a geologist in Africa but was now looking for a change of direction. Tayler, meanwhile, was pursuing postgraduate studies in anthropology at the University of Oxford.

Forman was impressed by the content and general approach of Piraparaná, but considered it too amateurish to be broadcast on television, so he made Moser an offer: Granada would give him a year's training as a professional film-maker, whereafter it would finance the making of a series of films about indigenous peoples of Latin America under his direction. This was an offer that Moser was delighted to accept though, in the event, he then spent three years learning the craft of television film-making, mostly on Granada's World in Action current affairs progamme, renowned for its investigative journalism. Eventually, in I968, as a result of a dispute between Granada management and the technicians' union, Moser found himself marooned in Bogotá with the time to prepare a proposal for the series, which he did with the assistance of his wife, the urban anthropologist Caroline Moser.

Integral to this proposal was the idea that each film would be directly based on the fieldwork of an anthropologist. Although he had never studied anthropology himself, Moser had long been convinced of the need to collaborate with anthropologists in making films about culturally exotic societies, not merely on account of their academic expertise, but also as a means of gaining a more intimate rapport with the subjects of the films. At this time, the standard model of British television programmes about exotic societies was either that of the scientific explorer in the David Attenborough mould, or that of the African safari expedition in the mould of Armand and Michaela Dennis. In both cases, the human subjects would typically be presented merely as one feature of a programme structured around the presenter's journey, which would also include sequences dedicated to natural history or the environment. Although the human subjects might be extensively talked about by the European presenter, they never spoke themselves. Moser was determined to go beyond this model and he saw collaboration with anthropologists as a means to achieve this, building upon the rapport that they had built up over years of fieldwork and their command of the subjects' language.

The proposal that Moser eventually submitted to Granada was entitled 'The Vanishing Tribes of Latin America'. It was readily accepted by Forman, but also had to be approved by the programme controller, David Plowright. Being a veteran of World in Action himself, Plowright insisted that the new series should not just be about traditional ways of life, but also about the forces that were threatening to destroy them. At Forman's suggestion, the series was dubbed 'Disappearing World'. 


\section{ThE BASIC FORMATS OF BRITISH TELEVISION ETHNOGRAPHIC FILM: THE 'ONE-BY-FOUR' VERSUS THE COMPARATIVE MODEL}

The first Disappearing World series consisted of three films about indigenous groups in Colombia, directed by Moser, and a fourth, actually the first to broadcast in May I970, about the Panare of southern Venezuela (among whom, by an entirely unrelated coincidence, I would carry out my own doctoral fieldwork five years later). Based on the field research of the French anthropologist Jean-Paul Dumont, Clearing in the Jungle was directed by Charlie Nairn, who, like Moser, had learnt his craft on World in Action. This proved to be merely the first of some sixteen Disappearing World series, in effect constituting a strand that would continue to be broadcast, albeit with various interruptions and many changes of personnel, until I993. Over this period, fifty-seven films were produced by the various Disappearing World teams (though not always under that series title), in a great many different locations around the world and on a broad variety of topics. ${ }^{6}$

Once it settled down, the ideal-typical format of films in the Disappearing World strand conformed to what one might call the 'one-by-four' formula: that is, a series of progammes of one television hour, each dealing with one social group and structured narratively around one central theme or topic as it affected an even smaller subgroup, sometimes no more than one or two principal families, even a single charismatic individual. These films were almost always based on the research of one anthropologist, who, typically, played an active part in making the film, both on location and back in the edit suite.

The roster of anthropologists who were involved with the strand was highly international. Many were only at the beginning of their careers when the films that they worked on were produced but they included such leading academic figures as Akbar Ahmed, Caroline Humphrey, Gananath Obeyesekere, Sherry Ortner, Andrew Strathern, Terence Turner and Annette Weiner. The films were also made to the highest technical standards, mostly by experienced and talented television crews. Among the cinematographers were Charles Stewart, Ivan Strasburg and Ernie Vincze. Among the editors were David Gladwell, Oral Norrie Ottey and Ted Roberts. Also involved was Dai Vaughan, who would later cut two films for David MacDougall as well as publish a number of thoughtful essays about documentary film editing. ${ }^{7}$

The Disappearing World strand also attracted a number of the leading British television documentary directors of the period. These included Mike Grigsby, much fêted at the time that the strand was launched for his Griersonian documentaries about North Sea trawlermen, and Leslie Woodhead who, like Moser and Nairn, and also Grigsby, was yet another film-maker 
who had been trained on World in Action. Already well-known for his drama-documentaries on Cold War topics, Woodhead only became involved in the strand by chance in 1974 when another distinguished director, Roger Graef, dropped out following Granada management's refusal, on budgetary grounds, to include a doctor in the team sent to make a film among the Mursi pastoralists of southern Ethiopia. Woodhead went on to direct a total of ten films for the strand, five of them about the Mursi in conjunction with the anthropologist David Turton, who from 1986 until it closed in I993 acted as adviser for the strand as a whole.

The strand also recruited and trained a number of anthropology graduates who in due course would go on to become leading directors of British ethnographic film in their own right, including Chris Curling, Melissa Llewelyn-Davies and André Singer. Moreover, as these directors moved on to other posts within British television, they took the Disappearing World format with them and ran similar series for other broadcasting companies. It was no exaggeration then for Turton to observe, in I992, of British television generally, 'Scratch almost any programme, on any channel, which can be described as anthropological and you are very likely to find a Disappearing World connection of one kind or another'.

However, although it may have been the dominant form, the Disappearing World one-by-four formula was not the only format based on the fieldwork of academic anthropologists to emerge during the 'golden era' of British television ethnography. There was also a more comparative format, initially favoured particularly by the $\mathrm{BBC}$ and also, much later, by the satellite-based television channels that came on stream in the I990s. In this comparative format, the duration of the programmes was also typically one television hour, but sequences from several culturally diverse societies would be juxtaposed as a series of segments within this hour. The links between these segments would then be made through voice-over commentary, sometimes in conjunction with pieces to camera by an on-screen presenter.

Whereas films in the one-by-four format could aim to communicate some sense of the experience of other ways of life and what this way of life meant to those who lived them, in the comparative format the segments of ethnographic footage were used merely to illustrate the verbal analysis. On the other hand, the comparative format opened up the possibility of using a television programme to make more theoretical anthropological propositions. In effect, the two formats, in their ideal forms, represented a mirror image of one another: while the one-by-four model offered ethnographic accounts of particular societies informed by an anthropological analysis, the comparative model represented an opportunity to present an anthropological analysis supported by ethnographic examples. 


\section{The DeVelopment of THE COMPARATIVE FORMAT}

The first television series in the comparative format based directly on the fieldwork of academic anthropologists began broadcasting in late I969, some months before the first Disappearing World programme was transmitted. This was Family of Man, a seven-part series produced and directed for the BBC by John Percival, a Cambridge social anthropology graduate. This series aimed to show the broad variety of ways in which the different stages of the human life cycle are experienced and managed through family organisation in a range of societies across the world. Each one-hour programme dealt with one particular life stage, from birth through to death, but involved the presentation of material shot in five different social groups. These groups included the Kawelka, a Papuan group living in the forested Hagen area of Highland New Guinea; the Pahari-speaking people of the village of Andheri, perched among the foothills of the Himalayas in northwest India and renowned for its polyandrous marriage practices; and the Hambukushu, Bantu-speaking agriculturalists and cattle-herders living on the savannas of the Okavango Delta region in northwestern Botswana.

The anthropologists on whose work these segments were based were respectively Andrew Strathern and Roger Ballard, both of whom were graduate students at Cambridge at the time, and Thomas J. Larson, an Oxford-trained anthropologist from the USA, recently appointed as a lecturer at the University of Witwatersrand. The programmes also included material shot with two British families, one a middle-class family living in Esher, a wealthy suburb in southwest London, the other a working-class family from Colne in Lancashire, in northwest England. However, in what would turn out to be a recurrent pattern, these British segments were not based on the research of anthropologist consultants.

Although the comparative ethnographic approach offered by the series was innovative and, even now, makes for interesting viewing, the format of Family of Man represented no more than an extension of an already wellestablished model. The various ethnographic segments within each programme were linked together by didactic explanatory pieces to camera by Percival himself, shot in the various different locations around the world and for which he always seemed to be wearing the same clothing, with only minor concessions to local climatological conditions. His voice was also laid over the images as off-screen narration as if it were a continuation of these synch to-camera pieces. This was a model that had long been employed in current affairs programmes on British television as well as in natural history series or 'safari' programmes. (Indeed, it is a model that continues to be widely employed to this day). The series also featured some relatively formal interviews, not only with the two English families in their homes, but also with individuals of the other groups. These interviewees spoke their own 
language, though their words, still just audible on the soundtrack, were then voiced-over in English. But the consultant anthropologists were neither seen nor heard.

Some years later, the BBC broadcast another series of ethnographic films under the title Face Values. This represented a somewhat different twist on the comparative format. The series was proposed to the BBC by a committee of the Royal Anthropological Institute (RAI), chaired by Sir Edmund Leach, though the idea appears to have first originated with Charles, Prince of Wales, who had recently taken over as the royal patron of the RAI and who had been taught by Leach when he was a student of anthropology at Cambridge in the mid-I96os. At a time when Britain was becoming an increasingly multicultural society through the effects of migration, Prince Charles saw the series as an opportunity to disseminate some insights from anthropology into the reasons for cultural difference and thereby help reduce prejudice against immigrant populations.

The series began production in 1976 and was broadcast in seven one-hour instalments in 1978. In contrast to Family of Man, which had presented cultural variation as largely a function of differences in family organisation, Faces Values was based rather on the idea of culture as a system of symbols that can be organised in a broad variety of ways. Instead of being structured around the major phases of the human life cycle, as Family of Man had been, each programme in the Face Values series explored cultural variation in ideas relating to one particular aspect of human life: gender, the body, space, ethnic identity, rites of passage and religious experience, also concepts of the past. As such, it reflected the impact on British social anthropology over the previous decade of the Lévi-Straussian structuralist ideas of which Edmund Leach had been a leading proponent.

The series drew on material based on the fieldwork of five anthropologists: Jeremy Boissevain in the parish of Naxxar on Malta, Patricia Caplan on the island of Mafia, off the coast of Tanzania (referred to in the series by the archaic name of 'Chole' on account of the potentially confusing associations of its more modern name), Anthony Forge on Bali, Anne Sutherland among the Gypsies of California and Terence Turner among the Kayapó of Central Brazil. The eminent Africanist anthropologist, Jean La Fontaine, acted as consultant for the series as a whole. As with Family of Man, the series also included some sequences shot in Britain, dealing with topics such as the treatment of the body at a health farm, spatial strategies at a campsite and the 'banging out' ceremony of a young printer in Birmingham completing his apprenticeship. However, as with Family of Man, although the publicity for the series went to some lengths to stress that anthropological concerns apply as much to 'ourselves' as to exotic Others, these British sequences were not based on systematic anthropological fieldwork. 
In terms of general format, this series was also different from Family of Man in one major respect, namely that there was no on-location presenter. In order to establish the connections between the ethnographic segments juxtaposed in each programme, a combination of two other devices was used instead. One of these was a conventional BBC commentary performed by a voice artist (who, unusually for the time, was female) while the other, quite different, involved none other than Prince Charles himself. In addition to introducing each programme, Charles appeared in a series of linking sequences, shot in a sumptuous drawing room in Windsor Castle, either speaking directly to camera or interviewing the consultant anthropologists, one by one, asking them a series of supposedly layman's questions. Otherwise, as in Family of Man, the anthropologists did not appear in person in these films (except sometimes fleetingly and by accident), though their voices were sometimes heard asking questions during interviews, which were subtitled, probably following the prior example of the Disappearing World series.

Although the series received high audience viewing ratings - primarily due to the involvement of Prince Charles - the critical response, both in the national press and among anthropologists, was mixed. The critics generally acknowledged the series to have been well-intentioned and laudably ambitious, and often pointed to one or more of the component ethnographic segments as being both effective and technically accomplished. But the balance of the reviews was generally on the negative side, particularly among those written by anthropologists themselves. There was a certain degree of mutual contradiction in these criticisms: some reviewers thought there was too much commentary, others thought there was too little; while some said the comments were too bland, others regarded them as too specialised. But the general tenor of the criticism was that the argument of the programmes was often either not clear or simply banal, and that the various different segments often did not hang together well, a fault that was not helped, a number of reviewers commented, by the transitions via Prince Charles in his drawing room at Windsor. ${ }^{10}$

It also later emerged that while making the series, there had been certain tensions between the BBC production team and at least some of the consultant anthropologists, both in the field and at the editorial phase. Almost forty years later, one of those involved, Patricia Caplan, was still feeling sufficiently marked by the experience to publish a scathing memoir, in which she commented that the films 'oversimplified to the point of distortion' and that messages that she sought to convey about her fieldwork on Mafia Island were sometimes entirely contradicted. ${ }^{11}$

While it is possible that some of the perceived shortcomings of the series might have been remedied with more effective linking devices or if the series producer, who had no background in anthropology, had been more 
attuned to the academic consultants' ways of thinking, there was also a more fundamental problem relating to the comparative format itself. It is one of the most basic principles of cross-cultural comparison that in order for such comparisons to be meaningful, it is necessary to provide sufficient context. This is difficult enough to achieve even in a textual form, where there is relatively little time constraint. But to make such comparisons, as Face Values sought to do, across three or more culturally diverse societies, based on the work of anthropologists approaching their material from a range of different angles, all in the course of a single television hour and in terms that would be readily accessible to a popular audience, was extremely challenging. It is little wonder then that the series received such mixed notices. Both the RAI and the BBC were chastened by the experience, indeed the latter so much so that when it set up a new ethnographic film series in Bristol in I979, the year after the broadcast of Face Values, it turned instead to the one-by-four format of Disappearing World. ${ }^{12}$

\section{The Disappearing World prototype: The Last OF THE Cuiva}

Although the basic features of the one-by-four format remained more or less fixed throughout the entire existence of the Disappearing World strand, in a more stylistic sense the strand changed in a number of significant ways over the years. In being structured around a denunciatory journalistic storyline, the first two series still bore the marks of the prior experience of the directors, Brian Moser and Charlie Nairn, on the current affairs strand, World in Action. Thus the first Disappearing World series, broadcast in 1970-7I, condemned the destructive impact of cattle ranchers, missionaries and road-building on the indigenous peoples of Colombia, while in the second series, broadcast in 1972 and consisting of only two programmes, Moser chronicled the devastating effect of the Vietnam War on the Meo (Hmong) in Laos, while Nairn exposed the negative influences of drought and tourism on the Tuareg of southern Algeria.

These storylines were delivered through a clear narrative structure, supplemented by various editorial devices characteristic of current affairs television: voice-over narration, 'talking head' interviews and explanatory graphics, particularly maps. They also often featured devices that were aimed at keeping the potentially disloyal viewer from switching off or changing channels. In the early films, these included a 'hook' placed at the head of the programme of some particularly dramatic material, sometimes as a pre-title sequence, while later films would also add a 'cliff-hanger', just before the commercial break, in which, typically, some dilemma or crisis is anticipated that will only be resolved after the break. There was also usually 
some sort of recapitulation of the storyline on the voice-over commentary track after the break, both to remind returning viewers and to orient any new viewers who might have switched on in the interim.

Traces of an earlier television format were also evident in the way in which the consultant anthropologists were presented in these early films. As in the scientific explorer format pioneered by David Attenborough as far back as the I950s, the anthropologists usually played a prominent on-screen part, often being introduced through establishment shots showing them directly involved in the life of the subjects. The anthropologists then acted as spokespersons for the subjects of the film, explaining through interviews or in voice-over how their societies were organised, what their core values were and how they were being affected by the threats to their traditional way of life. They sometimes also offered very personal subjective comments on the experience of carrying out fieldwork among the subjects of the film, and even about the experience of making the films. Although the subjects of the films did occasionally speak directly to the camera, their words were then voiced over in English, as in the Family of Man series.

Although it was actually the second Disappearing World film to be broadcast, The Last of the Cuiva, first screened in April I97I, served as a sort of baseline from which the series would later evolve. Directed by Brian Moser and based on the research of the French-Canadian anthropologist Bernard Arcand among a small group of hunter-gatherers living on the savannas of eastern Colombia, this film is also a testimony to the skills of the cameraman Ernie Vincze and the editor Dai Vaughan. Owing to its iconic status, I shall consider here in some detail.

The film opens with a highly cinematic pre-title sequence lasting 90 seconds without any music or commentary that it is impossible to imagine being permitted on British television today. This 'hook' starts with a closeup shot focused on a lattice of hammock threads that then pulls back to reveal a young Cuiva man sitting in the hammock looking directly and impassively at the camera. The sequence then cuts back and forth between a series of close-ups of the Cuiva in their forest camp and the cattle, horses, guns and drunkenness that are central to the llanero cowboy culture of the settlers invading the Cuiva's territory. On the soundtrack, throughout this pre-title sequence, there is nothing but the acute humming of forest insects (figure II.I).

After the title card, the film then reverts to a more current affairs authorial mode as Moser explains in voice-over, with the aid of maps, where the film is located and that the Cuiva, of whom very few remain, have been reduced to a fraction of their former territory. The film then returns to synch action and the conventional scientific explorer trope as Moser introduces us via the voice-over to a 'White man', that is, Bernard Arcand, making his way upstream to visit a previously uncontacted group of Cuiva. Arcand 

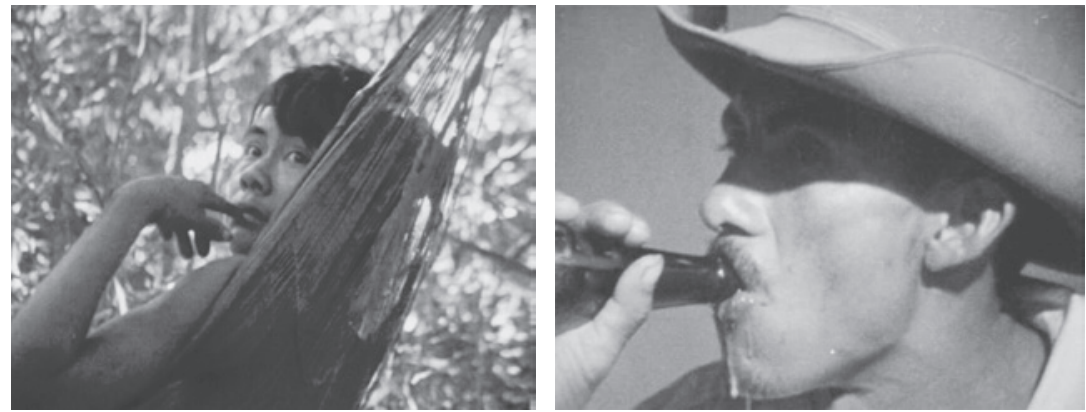

II. I The Last of the Cuiva (I97I) opens with a 90-second pre-title sequence intercutting images of the Cuiva and the cowboys threatening their way of life, with only the acute humming of forest insects for a soundtrack.

then takes over the voice-over narration and in a very laid-back way, supported by a series of equally leisurely quasi-observational sequences exquisitely shot by Vincze, he talks about the way in which the Cuiva live, their patterns of exchange, their high degree of nomadism, the division of labour between men and women, their use of hallucinogenic drugs. He frequently underlines the advantages of their 'original affluent society' over that of life in a 'modern' industrial society.

But these idyllic tranquil scenes are constantly intercut with sequences featuring the llaneros, which are not only generally much briefer but also more agitated and noisy, thereby evoking the threat to the Cuiva. Moser, off-screen, interviews some of these salt-of-the-earth cowboys and seems to be goading them into confessing that relations with the Cuiva have in the past been violent. However, it is not until two-thirds of the way through the film that we are finally presented with direct evidence of this violence as two Cuiva, a man and then a woman, in tight close-up, offer the most chilling but entirely deadpan first-hand accounts of the murder of their relatives by llaneros.

This testimony then segues into various sequences of life in the local llanero town where the Cuiva go to work in order to get the money to buy salt, alcohol, soap, clothes. There are sequences of a Catholic parade, cockfighting, cattle wrangling and even girls playing basketball, with the Cuiva looking on, seemingly marginal and disoriented. Arcand explains in an interview that there are two ways to destroy a society: the obvious way, through physical extermination, or through acculturation and the creation of dependence on externally produced goods. The film then ends with a classical reversion to the beginning as we return to the camp of the isolated group of Cuiva with whom the film had begun and observe them setting light to the savanna. Accompanied by a loud crackling sound, the final shots 
feature a man silhouetted against billowing smoke and the long grass in flames, ending the film on an apocalyptic note.

In a review of the films that had been produced for the strand by I980, Peter Loizos commented that Last of the Cuiva constituted 'a kind of prototype, which once made, could never again be equalled'. ${ }^{13}$ Yet while it is true that Last of the Cuiva served as a model for the strand as a whole, and also true that in terms of the quality of the film-making, it represents one of the high points of the tally of more than fifty films eventually produced, the strand did, however, undergo a series of gradual changes as it developed over the next two decades.

\section{The Refinement OF THE Disappearing $W$ ORLD FORMAT}

While the prospects for the survival of the Cuiva did indeed seem bleak, even at this early stage the general title of the Disappearing World strand was threatening to become a misnomer, at least in some cases. The Tuareg, for example, filmed for the second series, were certainly not in any imminent danger of disappearance, even if they were confronting the prospect of radical social change and political turmoil. By the time of the third series, consisting of two films broadcast in late I973, the strand title had become positively misleading. The first of these films, Kataragama - A God for All Seasons, directed by Charlie Nairn, concerned a festival in southeast Sri Lanka dedicated to a local god much admired for its ability to solve practical problems, while the other, Dervishes of Kurdistan, directed by Brian Moser, was about the ecstatic Qaderi Dervish cult in a village of refugee Iraqi Kurds living just over the border in Iran. The consultant anthropologist on the first film was the Sri Lankan anthropologist Gananath Obeyesekere, while on the second film, unusually, there were two consultants, André Singer and the Iranian anthropologist Ali Bulookbashi, both of whom had recently completed postgraduate degrees in social anthropology at Oxford.

In neither of these films was the principal storyline about the subjects' relationship with an 'outside world': the existence of neither the Sinhalese, nor the Qaderi Dervishes was then under threat, nor have they subsequently 'disappeared', even though both have been affected by major geopolitical conflicts originating far outside the immediate geographical region in which the films were made. If these two films had a common theme, it was rather about the disposition of religious believers to subject themselves to extreme bodily mortification. As shown very graphically in the films, this included pushing skewers through their cheeks in the case of the dervishes, and by suspending themselves from hooks pushed through the flesh on their backs in the case of the Sinhalese. 
This change in the general nature of the storyline became even more marked in the fourth series, which consisted of six films broadcast in late I974, with a further additional film broadcast in early 1975 as a sort of postscript. Not only was this the most extended series of the whole Disappearing World strand, but it could be argued that it represents the strand in its most classical form. However, with one exception, the subject matter of these films did not relate to external forces threatening the existence of the communities where the films were made but rather to internal events and processes. Moreover, in comparison to the films of the second series, the new series involved much stronger characterisation, with greater reliance on the subjects' own voices in both a literal and a metaphorical sense.

In part, these stylistic changes can be attributed to the influence of the anthropology graduates, Chris Curling, Melissa Llewelyn-Davies and André Singer who had by then been recruited to the Disappearing World production team, first as researchers and later as directors. This group in particular was greatly influenced by David and Judith MacDougall's film, To Live with Herds, which had recently won a prestigious prize at the Venice Film Festival. Moser had been alerted to the existence of this film by Colin Young, who had recently returned from the USA to head up the National Film School at Beaconsfield. Moser then arranged, sometime in I973, for To Live with Herds to be screened to the Disappearing World production team. While some members of the team were highly sceptical that such a leisurely paced film could ever be shown on British television, for others it was a revelation, proving that a film could be structured around the subjects' personal testimonies while still remaining highly engaging. ${ }^{14}$

Initially, however, the most immediately practical effect of this screening on the Disappearing World format was the adoption of subtitles. Although at first somewhat tentative and partial, it was this technical device, which, in effect, enabled the greater commitment to representing the voice of the subjects in the I974 series. The stylistic inheritance of World in Action still remained dominant in the form of extensive voice-over narration, explanatory graphics and interviews, but now the interviews were with the subjects rather than with the anthropologists. The subjects were also shown speaking to one another, without the intervention of either the anthropologists or the film-makers. Once central to the story, the anthropologists now only appeared in shot briefly, if at all, and although they might still have their say in the voice-over narration, often in a highly didactic fashion, the subjects themselves would typically now also play a leading role in explaining how their social institutions worked and what their key values were.

The opening film of the I974 series, The Mursi, directed by Leslie Woodhead and based on the fieldwork of David Turton exemplified the new approach. Here the the focus is not on the threat of change but on the political oratory of the Mursi cattle pastoralists of the Omo River valley 
in southern Ethiopia, as they find themselves involved in a war over grazing land with their traditional enemies, the neighbouring Bodi. The film begins with the familiar journalistic trope of the film crew arriving by air, accompanied by animated aerial maps, but this device is quickly left behind and the narrative thread develops instead around a number of key Mursi characters and their participation in a series of public political debates among senior men, mostly subtitled, about how they should react to the Bodi incursions into their territory. On the voice-over commentary track, Woodhead sets the scene and Turton provides contextualising explanations of a more comparative anthropological character, but there is no interview with Turton and he appears on screen only very briefly.

Although the prospect of imminent warfare lends a certain degree of spectacle to the film, as the Mursi warriors chant and brandish aloft their ancient rifles in a series of dramatic scenes, it is actually the form of the debates that constitutes the primary substance of the film. Indeed, around half the total duration of the film is dedicated to following the dynamics of these debates and to showing how, through a series of unspoken oratorical conventions, unanimity and collective solidarity is achieved. At the end of the film, the war with the Bodi remains unresolved, but narratively speaking this does not matter, as the viewer has been offered instead the satisfaction of having gained some understanding of how Mursi political oratory works. ${ }^{15}$

Similarly, Ongka's Big Moka, another well-known film from the I974 series, is not concerned with the threat of externally induced change but is rather focused on an entirely internal process. This was a major gift-giving ceremony, known as a moka, as practised by the Kawelka of Highland New Guinea, which, as elsewhere in Melanesia, is the means whereby a local political leader, a 'big-man', can establish his prestige and pre-eminence by outdoing potential rivals with his generosity. This film, directed by Charlie Nairn, was based on the fieldwork of Andrew Strathern, one of the three anthropologists who had previously participated in the Family of Man series. The narrative of this film revolves around the person of a particular charismatic 'big-man', Ongka, and it follows him as he goes about the wheeling and dealing necessary to assemble the vast numbers of pigs, cassowaries, cattle and other valuables - including a Toyota pick-up truck and a motorbike - that he plans to give away at a particularly extravagant moka (figure II.2).

Nairn's voice-over commentary is very extensive, while the subtitling is at best intermittent. Even so, Ongka's voice, both literally and metaphorically, is central to the narrative development of the film. Again, the process at the centre of the film remains unresolved at the end of the film since the crew had to leave before the final stage of the ceremony, which Ongka was obliged to postpone when a rival 'big-man', a certain Raima, intentionally circulated malicious rumours that caused social unrest and made the celebration of the moka impossible. But although this is somewhat disappointing, 

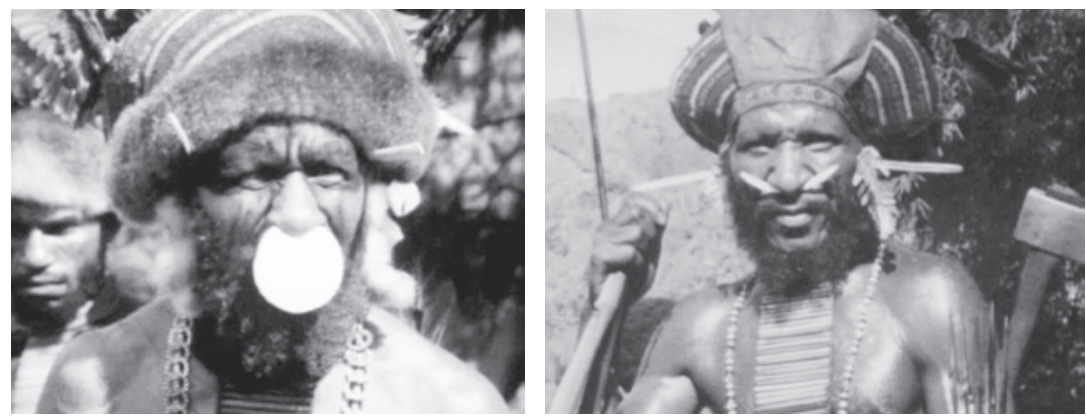

II.2 In Ongka's Big Moka (I974), two Melanesian 'big-men', Ongka, left, and Raima, right, compete for prestige in a moka gift-giving ceremony.

by the end of the film one feels that through the personal experience of Ongka and his long-suffering wife, Rumbocol, who has to look after all the pigs, one has been given a valuable insight not only into the moka itself but also into the values of Kawelka society more generally. ${ }^{16}$

Traditional ceremonial performance, this time relating to gender and fertility, was also central to another film in the series, The Mehinaku, which concerns the indigenous group of the same name who live in the Xingu Park in Central Brazil. This film was directed by the Argentinian director Carlos Pasini and was based on the fieldwork of the leading Amazonist anthropologist, Thomas Gregor. Again there is sympathetic characterisation of a number of central protagonists, while the narrative structure intrinsic to the preparation and performance of the ceremony provides the main backbone of the film. However, almost as an afterthought, the film then ends with a virtuoso 360-degree pan around a circle formed by all the living members of the Mehinaku village while a commentary voice laments that this generation will be the last to lead a traditional way of life. But the threat to this way of life is not otherwise referred to in the film and, moreover, it proved to be much less significant than the film-makers anticipated. The Mehinaku, along with a number of other indigenous groups of the Xingu, to this day continue to practise the traditional ceremonies that are the central focus of the film. ${ }^{17}$

Given this change in the focus of the films, the directors on the Disappearing World production team made a concerted effort around this time to change the title of the strand. But this was firmly resisted by the senior management of Granada Television: not only had Disappearing World by now become firmly established as a commercially valuable brand, but also, Denis Forman, whose personal interest had been responsible for bringing the strand into being in the first place, was adamant that 'salvage ethnography' should remain the series' highest priority since in his view there were still 

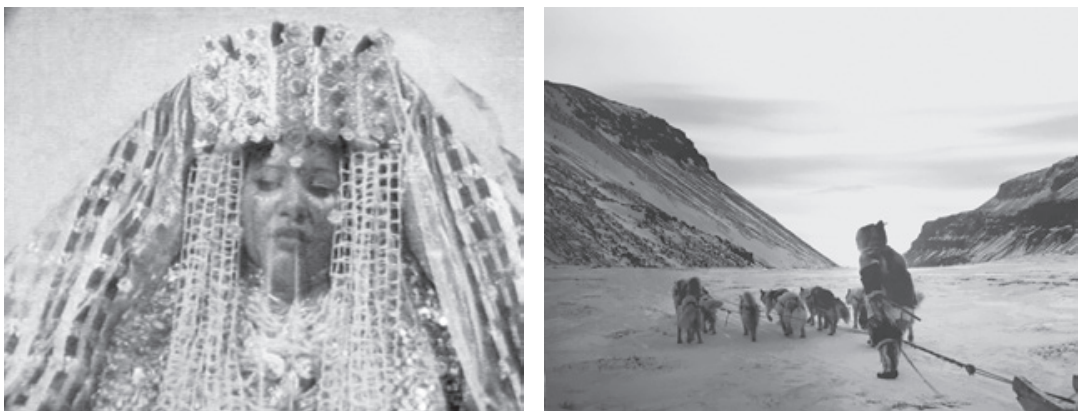

II.3 New 'ways of doing' ethnographic film for television, I977. Left, a veiled bride is displayed in Some Women of Marrakesh, the first film to be made by an all-woman crew; Eskimos of Pond Inlet, right, was innovative in that members of the community were consulted at all stages, including editing.

'whole tracts of the world with societies which should and must be recorded urgently before they go'. ${ }^{18}$

\section{Further innOVATIONS IN THE DisAPPEARING WORLD FORMAT}

Notwithstanding the retention of the anachronistic strand title, a number of further innovations in the Disappearing World format took place over the ensuing years. Some of these were stylistic, others more editorial. One of the latter concerned the representation of women - on both sides of the lens. One of the films of the 1974 series, Masai Women directed by Chris Curling and based on the field research of Melissa Llewelyn-Davies had broken new ground in British television ethnography - and possibly in anglophone ethnographic film in any medium - in presenting the life of a 'traditional' society from the perspective of the female members of the group. As such, it paralleled a similar tendency then emergent in ethnographic writing. ${ }^{19}$

Three years later, Llewelyn-Davies took this process one step further when she herself directed Some Women of Marrakech, broadcast in early I977. This film focused on the way in which the radical separation of the worlds of women and men required by Islam was experienced by women of various different social backgrounds in Morocco. It was based on the work of the late Elizabeth Fernea, an ethnographer who had written extensively about the seclusion of women in the Islamic world. This was the first documentary film on British television to be shot entirely by an all-women crew. Today, it seems remarkable that there was any resistance to all-women crews, but at 
that time, resistance there certainly was. Indeed, Llewelyn-Davies was only able to overcome this resistance by arguing that, given its subject matter, the film could only be made with an all-women crew since no man would be permitted to film Muslim women living in seclusion (figure II.3, left).

One scene that would certainly have been quite impossible to shoot without an all-women crew - a scene that would later cause considerable controversy - was shot in a women's communal bathhouse. Although they are filmed from a highly discreet angle, and no individual is clearly identifiable, it is clear that the subjects are entirely naked. Elizabeth Fernea reports that it was the subjects who suggested the shooting of this scene but on the condition that the all-women crew also remove their clothes. This represented something of a challenge for the film-makers, though Fernea, who was American, claims to have been less 'prudish' than her British colleagues. However, this shared experience proved to be an effective means for developing rapport with the subjects. ${ }^{20}$

The cinematographer on this film, Dianne Tammes, would later work as a member of another all-women Disappearing World crew when she shot Asante Market Women, broadcast in 1982. The sound recordist was Marilyn Gaunt, a distinguished documentary director-cameraperson in her own right, while the voice-over commentary was performed by the anthropologist Gillian Shepherd. The only man involved in a creative role on Some Women of Marrakesh was the editor, Dai Vaughan, who had cut The Last of the Cuiva and Masai Women and would also work on a number of Llewelyn-Davies's subsequent films. ${ }^{21}$

Some Women of Marrakech was also innovative in another way in that by using a qualified title, it sought to avoid the pretension that could be read into the use of the definite article in many earlier Disappearing World titles - The Tuareg, The Mursi, The Mehinaku - that is that they concerned the whole society, when in fact they usually only explored the lives of a very few people within those societies. In other respects, Some Women of Marrakech conformed in general stylistic terms to the standard Disappearing World format, notably in the use of formal interviews and an extensive voice-over commentary. In this last regard, however, the film was distinctive in that in contrast to the Disappearing World norm of commentaries that were generally merely contextualising, it offered what one reviewer called a 'feminist-ethnographic' analysis that went far beyond what was directly visible on the screen.

Thus at the end of the wedding that serves as the climax of the film, the commentary offers various observations on the symbolic significance of the event, concluding with the observation that 'every wedding re-enacts the drama of men's control over women's sexuality and fertility'. To reinforce the point, the film then ends with a coda in which a young schoolgirl chants her way uncertainly through a series of verses from the Koran which 
declare the authority of men over women because God has made them superior. $^{22}$

Another Disappearing World film broadcast in early I977 was Eskimos of Pond Inlet. This too was innovative, but in a very different way. Based on the fieldwork of the anthropologist Hugh Brody over two years in a small community on Baffin Island in the far north of Canada, in terms of content this film represented a return to the earliest Disappearing World series in that it was centrally concerned with the effects of contact with the 'outside world'. But in terms of film-making praxis, it was very different not only from any Disappearing World film that had come before but also from any that would come afterwards.

There is, for a start, no voice-over commentary of any kind; instead intertitle cards provide minimal contextualising information. There are no formal interviews, though the camera eavesdrops, as it were, as mostly elderly subjects talk around a kitchen table about the effects, mostly negative, of contact with the 'Whites'. The camera style is highly observational, with many long unbroken wide shots, including commanding shots of the vast landscape, with no zooms, very few close-ups or cutaways, and only minimal panning. The linear storyline found in so many Disappearing World films is also absent: instead the narrative proceeds through a series of loosely connected vignettes, gradually building up an overall impression of life in the community, a more elliptical movement aptly compared by one reviewer to the movement of the knight on a chessboard. ${ }^{23}$

In all these regards, stylistically speaking, Eskimos of Pond Inlet is by far the closest of all the Disappearing World films to the works of the MacDougalls and other exponents of Observational Cinema. But notwithstanding this similarity, the inspiration lying behind Eskimos of Pond Inlet actually came from another source entirely. The director, Mike Grigsby, had worked for many years for Granada Television, including on World in Action, but right at the beginning of his career he had been mentored by figures such as Karel Reisz and Lindsay Anderson, who came from the more poetic British documentary tradition originating in the work Humphrey Jennings. In fact, many of the observational stylistic features that distinguish Eskimos of Pond Inlet from the other Disappearing World films were already evident in Grigsby's earlier film, A Life Apart (I973), which concerns the life of the men on board a Fleetwood fishing trawler as it makes its way to Iceland. This film was shot by Ivan Strasburg while the sound was recorded by Mike McDuffie, both of whom then worked on Eskimos of Pond Inlet. ${ }^{24}$

As a director, Grigsby aimed to allow his subjects to speak directly to the audience as much as possible, with minimal intervention from the film-maker. In this regard, he found immediate common cause with Hugh Brody, who was keen that the film should provide a vehicle for the Pond Inlet Inuit to express their deep concerns about the threats posed by 
government measures aimed at limiting their rights over their land and its natural resources, particularly their right to hunt. This theme had been central to Brody's then recently published book, The People's Land (I975), whose title serves as a subtitle for the film.

Brody was also insistent that the film should be made with the active participation of the Inuit. Prior to the shoot, he spent two weeks in Pond Inlet seeking permission from the community to make the film and discussing with its members what should be included. He also agreed with them that a senior member of the community should come over to Britain and approve the final cut before the film was transmitted. As described in Chapter 5, participatory praxes were becoming increasingly common among ethnographic film-makers generally in the mid-I970s, but to the best of my knowledge, this was the only Disappearing World film in which a member of the host community played a direct role at the postproduction stage. ${ }^{25}$

\section{The LATER years OF DisAPPEARING WORLD: VARIATIONS IN CONTENT}

Although there were also a number of other innovations in the later years of the strand, these were more to do with issues of content than with transformations in film-making praxis. Two of the later series were shot in Communist states prior to the end of the Cold War, one in Mongolia, broadcast in 1975 and consisting of two films, the other in the People's Republic of China, which was broadcast in 1983 and consisted of three films. To a degree that is difficult to appreciate today, in the years prior to the collapse of the Soviet Union and the rise to power of Deng Xiaoping in China, relatively little was known in the West about the cultural life of even the majority populations of these countries, let alone their ethnic minorities. These films therefore opened up what were, in effect, entirely new worlds for most Western viewers, including many anthropologists. One of the main themes of these series concerned the way in which traditional cultural practices, far from 'disappearing', were being more or less successfully reconciled with the requirements of living in a Communist state. These series were therefore not broadcast under the standard series title, but rather as Mongolia and Inside China respectively.

The two films that made up the Mongolia series, On the Edge of the Gobi and The City on the Steppes were both directed by Brian Moser in collaboration with the veteran Sinologist and Central Asia specialist, Owen Lattimore, who had first visited the country in the I920s. The Disappearing World crew was the first Western documentary team to be allowed to film in Mongolia and, as Moser explains in a short prelude to each film, in accordance with the general terms of the agreement that gave them access, which had been 

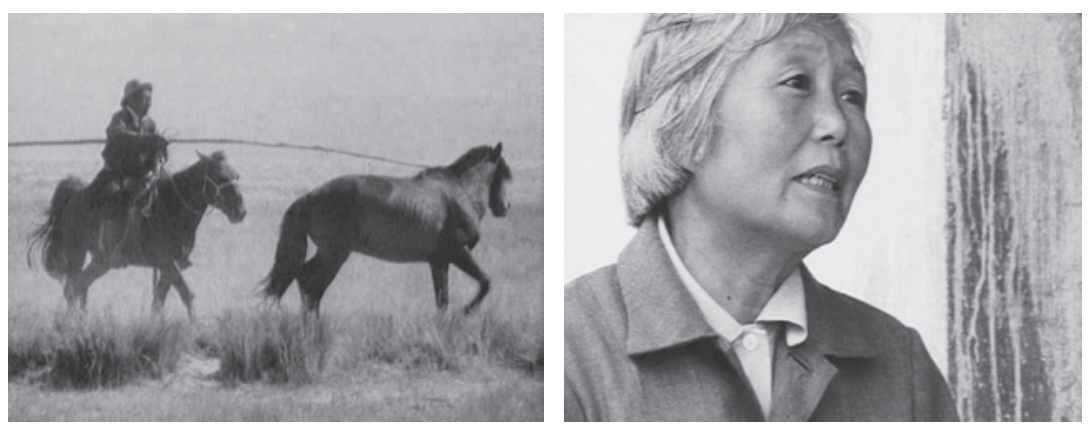

II.4 Newly appearing worlds in Communist Asia. Left, Mongolia: On the Edge of the Gobi (1975) showed how traditional pastoralism on the steppes was adjusting to collectivisation; right, 'If a girl is born, your roof will lower three feet.' Inside China: Living with the Revolution (I983) celebrated the passing of old attitudes.

negotiated by Lattimore on the basis of his long-standing contacts, the crew was accompanied at all points by various minders who were charged with ensuring that the films offered a positive image of their country. These minders controlled the subject matter of what Moser and his crew were able to film, down to the level of the individual shot.

In authorial terms, no doubt at least partially in response to these difficult shooting conditions, Mongolia represents something of a return to the format of The Last of the Cuiva, with Lattimore playing the role of Arcand in that earlier film in the sense that he is frequently present on screen and acts as the main guide and explicator of Mongolian life, either through informal to-camera pieces or in voice-over. Apart from some very brief exchanges between Lattimore and a Heroine of Socialist Labour, and later with a herder and then a schoolgirl who wants to become a teacher, no Mongolian subject speaks to the camera, and even the exchanges between subjects themselves are no more than sporadically subtitled.

Even so, notwithstanding these constraints, by virtue of Lattimore's obviously relaxed relationship with the subjects, the magnificent cinematography of Ivan Strasburg, the equally magnificent cutting of Jane Wood and Dai Vaughan, not to mention Moser's directorial skill in welding all these components together, the result is two films that manage to present the extraordinary beauty of the landscape, the people and their interaction with their animals alongside an ironic, almost surreal vision of the Mongolian version of Soviet kitsch. At the same time, Lattimore draws on his deep-seated knowledge of the country to offer a series of interesting insights into the many ways in which Mongolian people are seeking to reconcile traditional customs and processes with the organisational structures and attitudes of Socialist modernity (figure II.4, left). 
Similar themes were central to the three films of the Inside China series. Permission to make these films was negotiated at the highest levels, involving banqueting in London at the Chinese Embassy and even a Granada Television delegation to Beijing led by Sir Denis Forman. During the shoots, the Disappearing World crews were always accompanied by a team of minders from Chinese state television, CCTV, but although this had its frustrations, the constraints on the process of production appear to have been considerably less than they had been with the Inside Mongolia films. ${ }^{26}$

Two of the Inside China films were directed by Leslie Woodhead and were shot in two different peri-urban Han village communes near the industrial city of Wuxi, located on the north side of Taihu Lake, in the hinterland of Shanghai. The third film concerned the Kazakhs of Xinjiang in northwestern China and was directed by André Singer, by then the Disappearing World series producer. This particular Chinese ethnic minority group was selected because Singer thought it would be interesting to make a film about an Islamic pastoralist society in China which could then be paired with an earlier film in the strand about a similar Islamic pastoralist group, The Kirghiz of Afghanistan. There was also a plan to make a film about a second ethnic minority, this time in Yunnan province in southwestern China, but this fell foul of a union-management dispute within Granada Television about crewing levels. In order to make up a trilogy, the material filmed in the Wuxi communes by Leslie Woodhead and his team was used to cut two films.

The selection of these communes as a location for filming was a matter over which the Disappearing World team had relatively little control. Originally, Singer had wanted the film to be made in Kaixian'gong, a village on the south side of Taihu Lake where the renowned Chinese anthropologist and student of Malinowski, Fei Hsiao-T'ung, had carried out his doctoral fieldwork in the late I93os. However, the CCTV minders informed the Disappearing World team that 'suitable accommodation' was not available in Kaixian'gong, and directed them instead towards shooting in the more prosperous Wuxi communes, which were about 25 miles away by road. This was far from ideal from the Disappearing World team's point of view, but it was made clear to them that they would have to film there or not all. The film-makers had to content themselves therefore with a voice-over statement at the beginning of the first film to the effect that the Wuxi area is wealthy by rural standards in China and viewers should therefore not assume that they are representative of China as a whole.

Within these constraints as to location, the directors of the Inside China films had a relatively free hand in choosing what and with whom to film, though the presence of the minders would obviously have affected the way in which the subjects reacted to being filmed.The film-makers also remained heavily dependent on the minders to help them identify protagonists and 
situations in which to film, particularly since contrary to the Disappearing World norm, the ethnographic consultants - the anthropologist Barbara Hazard in the case of the Wuxi communes and the ethnolinguist Shirin Akiner in the case of the Kazakhs - were recruited to their respective films after all the decisions about location had been taken and, moreover, were not personally familiar with the specific communities in which the films were to be made.

Despite these limitations, the three films of the Inside China series offered Western audiences an intimate view of everyday life in rural China that was still highly unusual for the period. This was particularly true of The Kazakhs: the eminent Sinologist anthropologist, Stephan Feuchtwang, commented on reviewing the film that 'we have ... never even read, let alone seen, details of a north-western minority nationality of contemporary China'. He then commended the film for showing, albeit more through visual means than through explicit commentary, the many tensions between traditional custom and the encroaching sinicisation associated with political developments. ${ }^{27}$

Although perhaps not quite so unusual, the Wuxi films also impressed critics, at least in the mass media, because they located the well-known facts of recent Chinese history in the experience of two contrasting families. Far from being drab automatons dressed in Mao suits, as Chinese peasants were popularly deemed to be in the West at that time, these two families proved themselves to be as engaging, accessible and as varied in character and temperament as any other group of human beings. The first of the Wuxi films, Living with the Revolution, compares life before and after the revolution of $\mathrm{I} 949$, contrasting the bitter experiences of the pre-revolutionary period, including the Japanese invasion, with the experience of life under the Communists. The subjects explain that the Communists were initially feared, but later accepted for the many improvements that they brought to village life, particularly for women, despite certain errors in the policies of collectivisation and the excesses of the Cultural Revolution (figure II.4, right). However, these political themes, mostly presented through interviews, are skilfully interwoven with the events surrounding a wedding, the conduct of which shows just how much traditional cultural norms survive, despite the political changes.

In the second film, The Newest Revolution, attention turns to the way in which the village was by then adjusting to the post-Maoist return to family-centred economic production and the encouragement of a new interest in the acquisition of consumer goods such as televisions and washing machines. The film suggests a tension between the individualism encouraged by this new materialism and responsibilities to the collective interest, particularly of the young towards the old. These political themes are again explored and presented through the personal experiences of the 
same two families that featured in the first film. Although some critics with specialist knowledge of China complained that the film-makers had not been sufficiently critical of the testimonies offered by the films' protagonists, these two films were certainly successful in giving a strong sense of how Chinese political events of those years were being experienced at a grass-roots level. $^{28}$

Another innovation in the later years of the Disappearing World strand, reflecting, even if somewhat belatedly, a concurrent change of emphasis in academic anthropology, was the making of films about European communities. The first of these, The Basques of Santazi, broadcast in I987, concerned a Basque village on the French side of the Pyrenean border with Spain. This too was directed by Leslie Woodhead and was based on the work of the Oxford-based US anthropologist Sandra Ott. These European films were still mostly about rural communities, however, though an exception was Across the Tracks, broadcast the following year, which concerned a group of Vlach Gypsies living on the outskirts of a provincial town in the then still-Socialist state of Hungary. Directed by John Blake and based on the research of anthropologist Michael Stewart, this film was somewhat more observational than many films in the strand, though it also featured its fair share of standard television authorial devices. These included an archetypal 'cliff-hanger' at the end of Part I, whereby the viewer is left to wonder over the commercial break whether a much-loved and economically valuable mare, which had had problems in giving birth, will be saved by the offering of two candles to the Virgin Mary. Happily, in Part 2, after the commercial break, the Virgin accepts the candles and the horse survives.

But perhaps the most significant innovation in terms of content in the latter years of the strand was the practice of returning to a community where a previous Disappearing World film had already been made. By far the most elaborate example of this was the cycle of five films about the Mursi pastoralists of southern Ethiopia, all directed by Leslie Woodhead and based on the fieldwork of David Turton, which were made over a period of almost twenty years. Following the film from the I974 series about political oratory, Woodhead and Turton made a second film, broadcast in I982, dealing with the Mursi's symbiotic relationship with the Kwegu, a neighbouring population of hunters and settled cultivators. They then made a third film examining the more long-term movements of the Mursi population. Even at the time of the first film, when the subject of the Mursi's political oratory had been the warfare arising from their movement into Bodi territory, Turton had been aware of a long-term pattern whereby the Mursi were moving north from their traditional territory around the lower Omo River up into the Mago valley, in search of what they termed 'cool ground', that 

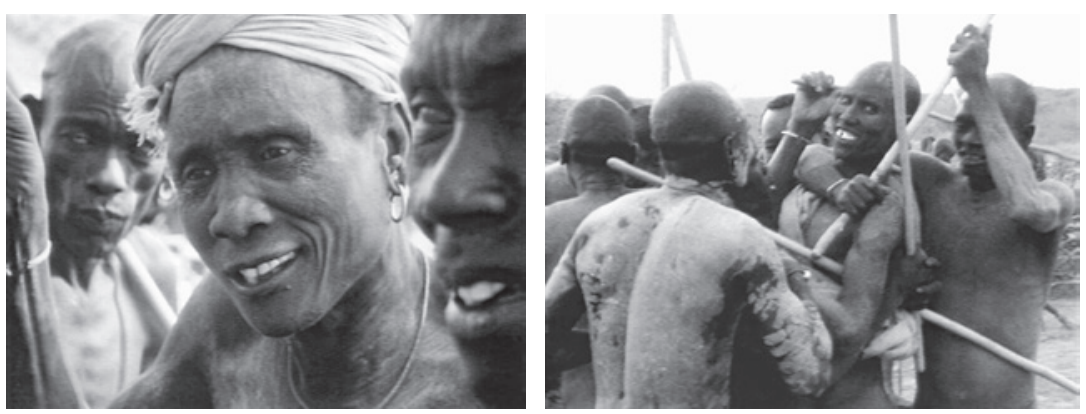

II.5 Films about the Mursi age-set ceremony (I99i). Left, 'That's terrible!' - in The Land is Bad, the Mursi are incredulous that in the film-makers' society, there is no age set ceremony; right, among the Mursi, as in Nitha, an age set has to fight the one above it - symbolically - in order to enter the adult age grade.

is, higher ground, less subject to drought and which could provide better grazing for their cattle. In I985, this historical process became the focus of The Migrants, which was broadcast as part of a trilogy, In Search of Cool Ground, along with re-versions of the two earlier films. ${ }^{29}$

The Migrants highlighted the various threats that the Mursi's new location in the Mago valley entailed for their traditional way of life. One of these was the presence of the tsetse fly, which threatened to destroy their cattle. This was a very serious matter for, as Turton explains in the film, cattle are not only of great material significance to the Mursi but also the key to their cultural identity. Other threats were implicit in the new proximity of the small Ethiopian town of Berka. Previously the Mursi had had very little contact with the 'outside world', but now they had become regular visitors to the Berka market and, at the same time, were increasingly under the control of the Ethiopian state: several Mursi had been drafted into the Ethiopian army and had been on active service in the Ogaden and Eritrea.

These threats would become the focus of the fourth and fifth films in the cycle, The Land is Bad and Nitha, broadcast consecutively in I99I (figure II.5). The first of these showed that the Mursi were now faced with severe famine and raids by neighbours armed with Kalashnikovs, while the second followed a major ceremony, the nitha. This involved the initiation of a new age-set of young men, which the Mursi saw as being essential to guarantee their future, particularly at a time of such crisis as they were then undergoing.

In effect, then, this cycle of Mursi films had brought the Disappearing World strand back to the themes of the very first series, that is, the effects of social and cultural change, the relationship with the 'outside world' and 

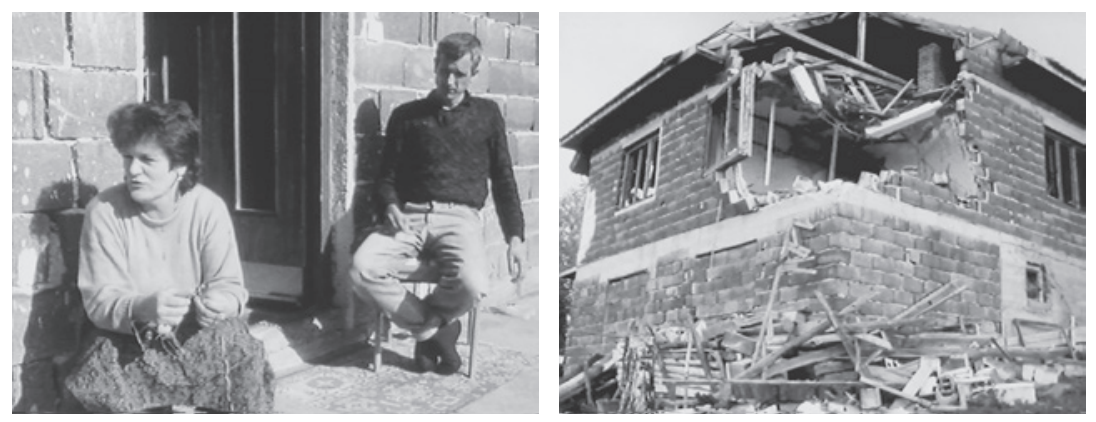

II.6 We Are All Neighbours (I993). Left, Nusreta and Nuria, Bosnian Muslims, listen anxiously to the Serb bombardment of distant Sarajevo.

But in the end, right, their house was destroyed by their Croatian Catholic neighbours.

the threat that these represented to the very physical existence of the societies concerned.

\section{The final Disappearing WORLD SERIES: THE RETURN TO THE BEGINNING}

This return to the earliest concerns of the strand became even more marked with the very last series, broadcast in 1993 under the executive direction of David Wason. This dealt explicitly with the devastating impact of externally generated warfare on three communities, the Uduk in the Sudan, the Karen on the border of Myanmar with Thailand, and Visnjica, a mixed Catholic and Muslim village in the heart of Bosnia-Herzegovina. While the first two films were shot in refugee camps or villages where the effects of warfare were already all too apparent, when filming began for the third film, We Are All Neighbours, the conflict arising from the break-up of Yugoslavia was still something that was happening at a certain distance, though even as the film opens, the soundtrack is punctuated by the dull but disconcerting sound of distant heavy gunfire (figure II.6, left).

Based on the fieldwork of the Norwegian anthropologist, Tone Bringa and directed by Debbie Christie, the opening scenes of We Are All Neighbours show Catholic and Muslim families living peaceably side by side as they had done for generations, symbolised particularly by visits to one another's houses to drink coffee. But as the war approaches, it becomes necessary for all families to take sides, with the result that friendship between neighbours breaks down and the coffee drinking comes to an end. Religious and ethnic identity, previously ignored in everyday life, becomes crucial, so that people who had had friendly and mutually supportive daily contact start avoiding 
one another and militias from each ethnic-religious group begin to patrol the streets at night. The film concludes with a deeply sombre coda, shot after the village had been over-run by Croatian paramilitary forces. The houses of the Muslim villagers, where earlier in the film scenes of happy family life had taken place, are now shown abandoned and bombed out, while the Catholic houses remain in pristine condition with neatly tended gardens (figure II.6, right). Most of the Muslims have fled and many have been murdered, not by any invading army, but by the very neighbours with whom they had lived in harmony for so long. The survivors who have taken refuge elsewhere declare that even should peace return, they will never return to Visnjica.

As the anthropologist Patricia Caplan commented in a review, although the strand title might sometimes have aroused negative comment in the past, in this film, 'we watch a world literally disappear before our eyes'. Indeed, this film offers a unique and riveting first-hand participant-observer account of the way in which friendship can be gradually corrupted by hatred, and peace by warfare, in a situation of interethnic tension vitiated by nationalist sentiments. It may have been one of the last to be made, but We Are All Neighbours is without doubt one of the most powerfully affecting as well as one of the most ethnographically significant of the entire strand of Disappearing World films. ${ }^{30}$

\section{Notes}

1 British anthropologists or those based in Britain who made films prior to the period of television patronage included Beatrice Blackwood (in the I930s), Ursula Graham Bower (I930s-I940s), Colin Turnbull (I950s-I970s) and James Woodburn (I960s). However, by far the most prolific was Christoph von Fürer-Haimendorf, who between I 940 and I976, assisted by his wife Betty, shot some $50-60$ hours of I6 $\mathrm{mm}$ film in India and Nepal. Some of Haimendorf's footage was assembled into television programmes by the BBC and he also made two independent films of his own. But his primary purpose was not to make narrativised documentaries as such but rather to produce visual documentation. He therefore did little to circulate his material around professional circles and some of it he may not even have looked at himself. For further details on these pioneers based in Britain, see my website on early ethnographic film, www.silenttimemachine.com. Specifically on Haimendorf, see Alan Macfarlane (2010) while on Ursula Graham Bower, see the material that MacFarlane has put up at https://upload.sms.cam.ac.uk/collection/I8Io528.

2 Singer (1992), 269-70.

3 Forman underlined the importance to him of Frazer's classic work during an interview with Jeremy Isaacs for the BBC programme, Face to Face, in October 1997.

4 Forman (I985), 3.

5 Moser and Tayler (1963); Forman (I985), 2-3; Moser (I988), 9-IO; also Brian Moser (personal communication, October 20I4).

6 In referring to Disappearing World as a 'strand', I follow the common usage in British television, employing this term to refer to what is, in effect, a series of programme series, each of which may consist typically of between three and twelve individual programmes. 
7 Vaughan (1999).

8 Turton (1992a), 284.

9 See Prince Charles's preface to the book that was published to accompany the series (Sutherland I978).

10 See, for example, the reviews of the series and the accompanying book that appeared in RAIN, the RAI newsletter, and the response to these from the series adviser Jean La Fontaine (RAIN, no. 27, I978), 6-IO.

11 See Caplan (20I3); (20I4), I5.

12 The BBC did not, however, entirely abandon its support for the comparative format in that they would later act as one of the co-sponsors, along with a long list of US television production companies, of Millenium: Tribal Wisdom and the Modern World, a ten-part series that was broadcast in the USA in 1992 and in Britain the following year. This drew on footage shot among twelve different indigenous peoples from around the world, as well as a number of sequences shot in US cities. It was presented by the eminent Amazonist anthropologist David Maybury-Lewis, who since the I970s had been an active campaigner for indigenous rights. It was directed by Adrian Malone, who had first made his name producing the celebrated $\mathrm{BBC}$ series, The Ascent of Man some ten years previously but who had since moved to Los Angeles. However, notwithstanding the great expertise of Maybury-Lewis and Malone in their respective fields, and their shared and entirely laudable intention to encourage respect for the wisdom of indigenous peoples, the series was subjected to some harsh criticism by both anthropologists and television critics, and was screened by the BBC, 'almost surreptiously', as one commentator put it, in a Sunday afternoon slot (Beidelman I992: Knight I993: Benthall 20I4).

13 Loizos (I980), 577.

14 Brian Moser (personal communication, October 20I4), see also the comments of Melissa Llewelyn-Davies in Grimshaw (I995), 4I-2. For a discussion of To Live with Herds itself, see Chapter 5, pp. I57-9. The role of Colin Young in promoting ethnographic film in the UK is discussed in Chapter Io, pp. 304-6.

15 However, in an article written many years later, David Turton (I992b), I7I-3, laments the fact that as a result of the need to cut down the four debates in the film in order to make them accessible to a British television audience, coupled with the limitations of subtitling at that time, the oratical performances lost much of their "complexity, richness and therefore meaning ... for the participants', or so he felt when he screened the completed film back to the Mursi in 1985. Leslie Woodhead (2006) has also written about the experience of making The Mursi from his perspective as the director of the film.

16 Andrew Strathern, the consultant anthropologist, also later wrote an interesting account of the making of this film (Strathern 1977).

17 See Chapter 7, pp. 216-I8.

18 Forman (1985), 3.

19 See Grimshaw (200I), I57. I return to Masai Women in Chapter I2, pp. ooo-ooo.

20 Fernea (1998), 65-8.

21 See Chapter I2, pp. 357-68 in which I discuss Llewelyn-Davies's films at greater length. Marilyn Gaunt would later work again with both Elizabeth Fernea and Dianne Tammes when she directed Women of the Middle East, a series of three films about women in the Islamic world broadcast by Channel 4 in 1982 (See Appendix, p. 494).

22 For a review of the film from a feminist perspective, see Brown (1978). A shorter film cut from the same footage and emphasising the more strictly religious aspects of Moroccan women's lives was released in 1979 under the title, Saints and Spirits: Religious Expression in Morocco.

23 Wright (I992), 279.

24 The editor of Eskimos of Pond Inlet was David Gladwell, who a decade previously had cut Piraparaná, the film directed by Brian Moser and Donald Tayler which had 
so impressed Sir Denis Forman and which had thereby led, indirectly, to the creation of Disappearing World. In the interim, Gladwell had worked on a number of major feature films with Lindsay Anderson. Some years later, he would cut 1919, a fictional feature film directed by Hugh Brody about an imagined meeting between two of Sigmund Freud's former patients.

25 For an account of the process of making this film, see Brody (I977).

26 In describing the Inside China series, I draw on the account by Alan Jenkins, which was based on interviews with many of those involved, including André Singer, Leslie Woodhead and Denis Forman (Jenkins 1986).

27 Feuchtwang (1983).

28 In common with some of the specialist reviewers in the UK national press, Alan Jenkins claims that the oral testimonies that are a central feature of these films conform to a well-established propaganda genre of 'speaking bitterness' about social conditions prior to accession to power of the Communist Party in 1949 (Jenkins I986), I2.

29 See Turton (1988) for a more detailed historical discussion of Mursi migration over the long term.

30 See Caplan (1993), 20, also Tone Bringa's book about Visnjica, which describes the background to the conflict and also refers to the film (Bringa 1995). Later, between I999 and 200I, Bringa collaborated with Peter Loizos in making a follow-up film, Returning Home, based on interviews with displaced families from both sides of the ethnic divide. 